\title{
Staff awareness of cost of anaesthetic drugs, fluids, and disposables
}

Recently reports have highlighted the cost of anaesthetic agents and how the cost of giving an anaesthetic has increased in real terms. ${ }^{12}$ Awareness by staff of the price of drugs, intravenous fluids, and equipment may influence their familiarity of theatre nurses with some items led them to give grossly inaccurate estimates of cost. More alarming is the consistent underpricing of the agents that Lethbridge $e t$ al showed were the main cause of rising costs;

\begin{tabular}{|c|c|c|c|c|c|c|}
\hline & \multirow[b]{2}{*}{$\begin{array}{c}\text { Actual } \\
\text { price }(\mathfrak{£})\end{array}$} & \multicolumn{5}{|c|}{ Estimated price $(\mathfrak{E})$} \\
\hline & & Consultants & Juniors & $\begin{array}{c}\text { Operating } \\
\text { department } \\
\text { assistants }\end{array}$ & Theatre nurses & $\begin{array}{l}\text { Intensive care } \\
\text { unit nurses }\end{array}$ \\
\hline \multicolumn{7}{|l|}{ Disposables: } \\
\hline 23g Butterfly & $0 \cdot 20$ & $0.53(0.20)$ & $0.32(0.21)$ & $0.30(0.19)$ & $0.61(0.62)$ & $0.58(0.26)$ \\
\hline l6g Cannula & 0.48 & $0.85(0.44)$ & $0.66(0.42)$ & $0.69(0.44)$ & $0.56(0.34)$ & $0.82(0.45)$ \\
\hline $1 \mathrm{ml}$ Syringes & 0.08 & $0.26(0.24)$ & $0.17(0.06)$ & $0.17(0.20)$ & $0.26(0.20)$ & $0.10(0.02)$ \\
\hline $2 \mathrm{ml}$ Syringes & 0.04 & $0 \cdot 29(0 \cdot 18)$ & $0.15(0.08)$ & $0 \cdot 19(0 \cdot 20)$ & $0.31(0.23)$ & $0.06(0.05)$ \\
\hline $10 \mathrm{ml}$ Syringes & 0.09 & $0.29(0.24)$ & $0.18(0.11)$ & $0.23(0.21)$ & $0.48(0.34)$ & $0.14(0.06)$ \\
\hline Intravenous infusion set & 0.93 & $2 \cdot 32(1 \cdot 23)$ & $1.76(0 \cdot 74)$ & $2 \cdot 15(1 \cdot 01)$ & $2 \cdot 86(1 \cdot 37)$ & $2.07(1 \cdot 22)$ \\
\hline Electrocardiography electrodes (3) & 0.57 & $1.13(0.50)$ & $0.77(0.39)$ & $0.80(0.67)$ & $1 \cdot 74(1 \cdot 39)$ & $0.38(0.22)$ \\
\hline Reel of Micropore 1 inch & $0 \cdot 19$ & $1.91(1.59)$ & $0.88(0.60)$ & $1.05(0.49)$ & $1.65(1.28)$ & $1.09(0.64)$ \\
\hline Reel of zinc oxide tape 1 inch & $0 \cdot 72$ & $1.03(0.71)$ & $0.87(0.68)$ & $0.83(0.51)$ & $1 \cdot 10(0.76)$ & $1 \cdot 10(0.58)$ \\
\hline Portex endotracheal tube size 8 & 1.63 & $1.63(0.68)$ & $2 \cdot 98(2 \cdot 20)$ & $2.50(2.01)$ & $4.00(1.46)$ & $2 \cdot 11(0.89)$ \\
\hline Leadercath central line & $8 \cdot 24$ & $4.83(1.86)$ & $9 \cdot 14(7 \cdot 29)$ & $5.09(3.63)$ & $5.48(3.19)$ & $4.87(2 \cdot 52)$ \\
\hline \multicolumn{7}{|l|}{ 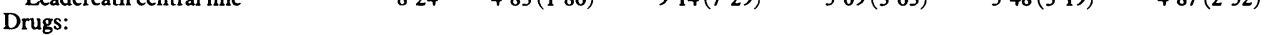 } \\
\hline Thiopentone $500 \mathrm{mg}$ & $1 \cdot 49$ & $1.03(1.44)$ & $1 \cdot 28(1.45)$ & $2.65(2.86)$ & $5.09(5.55)$ & $2 \cdot 13(1 \cdot 62)$ \\
\hline Etomidate $1 \times 10 \mathrm{ml}$ ampoule & 1.05 & $2.37(1.88)$ & $1.27(0.48)$ & $2 \cdot 10(2 \cdot 47)$ & $3 \cdot 19(1.58)$ & $1.90(1.33)$ \\
\hline Pancuronium $1 \times 4 \mathrm{mg}$ ampoule & 0.67 & $0.75(0.51)$ & $0.70(0.53)$ & $0.88(0.84)$ & $2.41(2.01)$ & $1.35(1.16)$ \\
\hline Atracurium $1 \times 50 \mathrm{mg}$ ampoule & $1 \cdot 43$ & $1.97(1.31)$ & $1.79(1.06)$ & $1.46(1.07)$ & $2.62(1.92)$ & $1.70(1.43)$ \\
\hline Suxamethonium $1 \times 100 \mathrm{mg}$ ampoule & 0.31 & $0.34(0.25)$ & $0.47(0.26)$ & $0.72(0.62)$ & $2 \cdot 46(1 \cdot 17)$ & $1.40(0.99)$ \\
\hline Fentanyl $1 \times 100 \mu \mathrm{g}$ ampoule & 0.45 & $1.63(1.44)$ & $1 \cdot 17(0 \cdot 84)$ & $1.57(1.38)$ & $3 \cdot 40(2 \cdot 14)$ & $2.04(1.08)$ \\
\hline Fentanyl $1 \times 500 \mu \mathrm{g}$ ampoule & 2.05 & $4.66(2 \cdot 96)$ & $3.51(2.27)$ & $3 \cdot 12(2 \cdot 15)$ & $6 \cdot 16(3.90)$ & $4 \cdot 33(2 \cdot 47)$ \\
\hline Morphine $1 \times 10 \mathrm{mg}$ ampoule & $0 \cdot 17$ & $0.20(0.22)$ & $0.69(0.90)$ & $1.49(1.58)$ & $4 \cdot 29(4 \cdot 19)$ & $3.31(1.97)$ \\
\hline Halothane $1 \times 250 \mathrm{ml}$ bottle & $10 \cdot 49$ & $11 \cdot 12(7 \cdot 12)$ & $11.00(7.05)$ & $7 \cdot 25(5 \cdot 67)$ & $13.64(12 \cdot 10)$ & $5 \cdot 67(2 \cdot 74)$ \\
\hline Enflurane $1 \times 250 \mathrm{ml}$ bottle & 38.35 & $25 \cdot 40(11.03)$ & $25.04(8 \cdot 13)$ & $11.55(10.91)$ & $16 \cdot 40(17 \cdot 84)$ & $6.40(3.01)$ \\
\hline Isoflurane $1 \times 100 \mathrm{ml}$ bottle & 33.50 & $30 \cdot 47(20 \cdot 13)$ & $41 \cdot 12(17 \cdot 20)$ & $16 \cdot 80(13 \cdot 48)$ & $13 \cdot 14(12 \cdot 10)$ & $13 \cdot 60(16 \cdot 18)$ \\
\hline \multirow{2}{*}{\multicolumn{7}{|c|}{ Intravenous fluids: }} \\
\hline & & & & & & \\
\hline $5 \%$ Dextrose $500 \mathrm{ml}$ & 0.97 & $1.53(0.68)$ & $2 \cdot 18(1 \cdot 59)$ & $1.39(1.50)$ & $3 \cdot 74(2 \cdot 53)$ & $1.28(0.58)$ \\
\hline Haemaccel $500 \mathrm{ml}$ & $3 \cdot 81$ & $4 \cdot 38(2 \cdot 37)$ & $11 \cdot 90(14 \cdot 71)$ & $4 \cdot 71(3 \cdot 16)$ & $9 \cdot 05(6.75)$ & $4 \cdot 38(1 \cdot 87)$ \\
\hline 1 Unit whole blood & $21 \cdot 00$ & $38.04(26 \cdot 16)$ & $38.85(18.36)$ & $42 \cdot 80(18 \cdot 81)$ & $18.55(11.57)$ & $10 \cdot 41(8.50)$ \\
\hline 1 Unit fresh frozen plasma & $12 \cdot 25$ & $35.96(19.98)$ & $35 \cdot 00(18 \cdot 10)$ & $50.50(42.06)$ & $17 \cdot 15(9 \cdot 25)$ & $11 \cdot 11(10.98)$ \\
\hline $\begin{array}{l}1 \times 400 \mathrm{ml} \mathrm{Bottle} \mathrm{human} \mathrm{plasma} \\
\text { protein fraction }\end{array}$ & $24 \cdot 15$ & $38.90(25 \cdot 30)$ & $28.55(9.63)$ & $41 \cdot 00(27 \cdot 06)$ & $17 \cdot 44(9 \cdot 13)$ & $9 \cdot 78(7 \cdot 37)$ \\
\hline
\end{tabular}

practice and, ultimately, departmental expenditure. This study was undertaken to show the extent of this knowledge among various groups of staff who use anaesthetic drugs and supplies.

\section{Methods and results}

We prepared a list of commonly used drugs, disposables, and intravenous fluids. Subjects were asked to give the cost to the Leeds Eastern Area Health Authority of each item. We studied five groups of staff who use anaesthetics: consultant anaesthetists, junior anaesthetists, operating department assistants, theatre nurses, and intensive care unit nurses. Each group consisted of 10 subjects.

The mean and standard deviation of the estimated cost of each type of item used in anaesthesia (drug, fluid, or disposable) were calculated for each group of staff. These costs were compared with the wholesale price of the item or, for blood or a blood product, the price charged by Leeds Eastern Area Health Authority to private practice. Contract prices were not used as they are confidential information. The table shows the results. Most items were overestimated, with a few consistent exceptions: all groups underestimated the cost of naloxone and enflurane, and all but the junior anaesthetists underestimated the cost of isoflurane and a Leadercath central line.

\section{Comment}

As departmental budgeting is introduced, awareness of costs within departments should be encouraged. A previous report found that junior anaesthetists had a fair knowledge of costs ${ }^{3}$; we found that, though knowledge did not differ greatly among the groups studied, the lack of naloxone and enflurane were underpriced by all groups in our study, and isoflurane by all but the junior anaesthetists.

As Wickings et al implied in 1983, clinical costing studies ${ }^{2-4}$ will have little impact if not accompanied by powerful educational programmes. ${ }^{5}$ Drugs accounted for $8.3 \%$ of the total anaesthetic bill in $1978 .{ }^{2}$ If this figure rises and economic use of disposables and blood products is not encouraged there may be pressure to cut staffing levels, which are the major item in an anaesthetic department's budget. This study shows that awareness of the cost of anaesthetic drugs, intravenous fluids, and disposables is lacking among staff who use these materials.

1 Mosley H, Kumar AY, Bharvani Shankar K, Rao PS, Homi J. Should air-oxygen replace nitrous oxide-oxygen in general anaesthesia? Anaesthesia 1987;42:609-12.

2 Lethbridge JR, Secker Walker J. Cost of anaesthetic drugs and clinical budgeting. $\mathrm{Br}$ Med $\mathrm{f}$ 1986;293:1587-8.

3 Simpson PM. The cost of anaesthetic drugs and equipment. Anaesthesia 1978:33:53-9.

4 Bailey PW. Pricing of anaesthetic techniques. Anaesthesia 1978;33:235-41.

5 Wickings I, Coles JM, Flux R, Howard L. Review of clinical budgeting and costing experiments. BrMed F 1983;286:575-8.

(Accepted 3 November 1987)

\section{Killingbeck Hospital, Leeds LS14 6QU}

M J FAIRBRASS, MB, FFARCS, senior house officer A G CHAFFE, BM, FFARCS, senior house officer

Correspondence to: Dr M J Fairbrass, Department of Anaesthesia, Foothills Hospital, Calgary, Alberta T2N 2T9, Canada. 